\title{
Policy Debates
}

Edited by FIONA Wishlade

\section{Public Infrastructure Services in the European Union: Challenges for Territorial Cohesion}

\author{
JUDITH CLIFTON, DANIEL DÍAZ-FUENTES and MARCOS FERNÁNDEZ-GUTIÉRREZ* \\ Department of Economics, Faculty of Economics and Business, University of Cantabria, Avda. de Los Castros s/n, E-39005 \\ Santander, Cantabria, Spain.Emails: judith.clifton@unican.es,daniel.diaz@unican.es and marcos.fernandez@unican.es
}

(Received March 2014; in revised form April 2015)

Clifton J., Díaz-Fuentes D. and Fernández-Gutiérrez M. Public infrastructure services in the European Union: challenges for territorial cohesion, Regional Studies. Territorial cohesion has emerged as an important objective for European Union authorities, particularly since the Treaty of Lisbon. One important strand of territorial cohesion is citizen access to affordable public infrastructure services. While place of residence may influence use of services, insufficient evidence exists as to whether residence may constitute a disadvantage to citizens as regards service use. This paper assesses this by contrasting citizens' stated and revealed preferences for services in three large countries. Residence frequently conditions expenditure on public infrastructure services and satisfaction with service accessibility and affordability, disadvantaging residents in some territories, posing challenges for territorial cohesion.

Public infrastructure services Territorial cohesion Citizens Consumers Rural areas Regions

Clifton J., DíaZ-Fuentes D. and FernándeZ-Gutiérrez M. 欧盟的公共基础建设服务：领土凝聚的挑战， 区域研 究。领土凝聚, 已成为欧盟政府的重要目标, 特别是在里斯本条约之后。领土凝聚的其中一项重要组成, 便是公民能 够获得经济适用的公共基础建设服务。居住地虽可能影响服务使用, 但却未有足够的证据显示, 居住会对公民在服务 使用方面构成不利。本文透过对比三个大型国家中, 公民自身宣称和被揭露的服务偏好, 对上述问题进行评估。居住 经常限制了公共基础建设服务的扩张, 以及对服务可及性和经济适用性的满意度, 因此对部分领域中的居民产生不 利, 并对领土凝聚带来挑战。

\section{公共基础建设服务＼cjkstart领土凝聚＼cjkstart公民＼cjkstart消费者乡村地区区域}

Clifton J., Díaz-Fuentes D. et Fernández-Gutiérrez M. Les services d'infrastructure publics dans l'Union européenne: les défis pour la cohésion territoriale, Regional Studies. La cohésion territoriale s'est avérée un principal objectif des autorités compétentes de l'Ue, notamment depuis le Traité de Lisbonne. Un aspect important de la cohésion territoriale est l'accès des habitants aux services d'infrastructure publics abordables. Alors que le lieu de résidence pourrait influer l'utilisation des services, rares sont les preuves que le lieu résidence constitue un inconvénient pour les habitants en ce qui concerne l'utilisation des services. Cet article l'évalue en comparant les préférences déclarées et révélées des habitants à propos des services dans trois grands pays. Souvent, le lieu de résidence détermine les dépenses pour les services d'infrastructure publics et la satisfaction vis-à-vis de l'accessibilité et de l'abordabilité des services, ce qui défavorise les habitants de certains territoires, posant ainsi des problèmes en matière de cohésion territoriale.

Services d'infrastructure publics Cohésion territoriale Habitants Consommateurs Zones rurales Régions

Clifton J., Díaz-Fuentes D. und Fernández-Gutiérrez M. Dienstleistungen der öffentlichen Infrastruktur in der Europäischen Union: Herausforderungen für den territorialen Zusammenhalt, Regional Studies. Der territoriale Zusammenhalt

*Corresponding author. 
ist für die Behörden der Europäischen Union vor allem seit dem Vertrag von Lissabon zu einem wichtigen Ziel geworden. Ein wichtiger Aspekt des territorialen Zusammenhalts ist der Zugang der Bürger zu erschwinglichen Dienstleistungen der öffentlichen Infrastruktur. Während sich der Wohnsitz auf die Nutzung von Dienstleistungen auswirken kann, gibt es unzureichende Belege für die Frage, ob der Wohnsitz hinsichtlich der Nutzung von Dienstleistungen für die Bürger einen Nachteil darstellen kann. In diesem Beitrag wird diese Frage durch einen Vergleich der angegebenen und offengelegten Präferenzen von Bürgern für Dienstleistungen in drei großen Ländern untersucht. Die Ausgaben für Dienstleistungen der öffentlichen Infrastruktur und die Zufriedenheit mit der Zugänglichkeit und Erschwinglichkeit von Dienstleistungen werden häufig durch den Wohnsitz konditioniert, was Bürger in einigen Gebieten benachteiligt und den territorialen Zusammenhalt vor Herausforderungen stellt.

Dienstleistungen der öffentlichen Infrastruktur Territorialer Zusammenhalt Bürger Verbraucher Ländliche Gebiete Regionen

Clifton J., Díaz-Fuentes D. y Fernández-Gutiérrez M. Servicios de infraestructura pública en la Unión Europea: retos para la cohesión territorial, Regional Studies. La cohesión territorial ha pasado a ser un objetivo importante para las autoridades de la Unión Europea, especialmente desde el Tratado de Lisboa. Un aspecto importante de la cohesión territorial es el acceso de los ciudadanos a servicios asequibles de infraestructura pública. Aunque el lugar de residencia puede influir en el uso de los servicios, hay pruebas insuficientes sobre la cuestión de si la residencia podría suponer una desventaja para los ciudadanos en lo que respecta al uso de servicios. En este artículo evaluamos esta cuestión contrastando las preferencias indicadas y reveladas de los ciudadanos por servicios en tres países grandes. La residencia condiciona muchas veces el gasto en servicios de infraestructura pública y la satisfacción con respecto a la accesibilidad y la asequibilidad de los servicios, perjudicando a los residentes en algunos territorios, lo que plantea retos a la cohesión territorial.

Servicios de infraestructura pública Cohesión territorial

Ciudadanos Consumidores

Zonas rurales

Regiones

JEL classifications: L98, O18, R22, R58

\section{INTRODUCTION}

Territorial cohesion, incorporated into the Treaty of Lisbon as an explicit objective of the European Union (EU) (EU, 2007a), has emerged as a policy paradigm of territorial development in the EU (SANTINHA, 2014). However, the meaning of territorial cohesion in EU discourse and policy is complex and evolving (Medeiros, 2012; Colomb and Santinha, 2014; SANTINHA, 2014). Despite this, public infrastructure services, formally known as 'Services of General Economic Interest' (SGEI), are now understood by EU authorities to play an essential role in territorial cohesion (MEdeIROS, 2012). SGEI refers to those services that are subject to market rules, but also to public service obligations (PSO) and address the public interest (VAN de Walle, 2009). The Charter of Fundamental Rights of the European Union accompanying the Treaty of Lisbon (EU, 2007b) recognizes citizens' access to affordable SGEI as 'essential for territorial cohesion'. Since its inclusion is an explicit objective of the EU, territorial cohesion is becoming an increasingly important part of EU policy. For example, the Sixth Cohesion Report (EUROPEAN COMmission (EC), 2014) stressed the ongoing importance of improving citizen accessibility to services, including telecommunications, energy and transportation. Access to affordable SGEI is held to promote regional competitiveness, equity and balance, economic development and sustainability of rural communities (WARD and BROWN, 2009; European Observation Network for Territorial Development and Cohesion
(ESPON), 2013; SUBACCHI et al., 2014), and contribute to 'sustainable and harmonious territorial development of the European Union' (EU, 2011, pp. 8-9). According to Molle (2007, p. 283), territorial cohesion requires that 'people and firms are not unduly handicapped by spatial differences in access to basic services'. Therefore, though it is to be expected that the provision of public infrastructure services differs among territories, a core objective of territorial cohesion will be that the provision of public infrastructure services does not disadvantage citizens due to their place of residence (ESPON, 2007a; RAUHUT and LUDLOW, 2013).

Empirical evidence suggests there may be significant territorial differences in the use of public infrastructure services in the EU. Large differences exist, for example, across EU regions as regards internet use (RAUHUT and Ludlow, 2013). The 'digital divide' also exists in the EU across rural-urban spaces (SHUCKSMITH et al., 2009), as acknowledged by the Green Paper on Territorial Cohesion (EC, 2008). Less data are available on the use of other public infrastructure services. The most recent EUROSTAT (Statistical Office of the European Communities) Household Budget Survey (HBS) showed that EU households in sparsely populated areas dedicated a larger share of their total expenditure (57\%) to energy than those in densely populated areas (52\%) (EUROSTAT, 2005). Relative expenditure on 'Water supply and miscellaneous services relating to the dwelling, (including refuse and sewerage collection) was higher in densely populated areas (22\%) than in sparsely populated ones (17\%) (EUROSTAT, 2005). 
Beyond these figures, there is still insufficient evidence on the use of SGEI from a territorial perspective and the consequences for territorial cohesion (BUNDESTINSTITUT FÜR BAU-, STADT-, UND RAUMFORSCHUNG (BBSR), 2013; RAUHUT and LUDLOW, 2013; EC, 2014). In particular, there is insufficient research on whether differences in service use associated with place of residence constitute a disadvantage for citizens. This is an important question, especially in light of the new cycle of Cohesion Policy (2014-20), which prioritizes improving access to quality SGEI to correct territorial imbalances (EC, 2011), and also because the EU's promotion of territorial cohesion may require coordinating sectoral policies and integrating them 235 into a territorial perspective (EU, 2011; COLOMB and SANTINHA, 2014).

This paper provides empirical evidence on this question by analysing the provision of public infrastructure services in the EU from a territorial perspective. Two

240 dimensions are considered: differences among regions and differences between urban and rural areas. The paper enquires whether residents are disadvantaged by contrasting their use of - and their satisfaction with public infrastructure services. To do so, it follows the technique of contrasting revealed (RP) and stated preferences (SP), as described by WhITEHEAD et al. (2008). Through a micro-econometric analysis, the paper first explores the determinants of households' revealed expenditure on services, using national HBSs (Instituto Nacional DE Estadística (INE), 2006; Instituto Nazionale di Statistica (ISTAT), 2006; Office fOR NATional Statistics (ONS), 2006). Second, these results are contrasted with citizens' stated satisfaction with access (accessibility) and price (affordability) of services, based on the most recent Eurobarometer, which was dedicated to public infrastructure services (EC, 2007). This survey constitutes an important source for this paper, as it uniquely incorporated information about all citizens (both users and non-users), included data on territorial dimensions (region of residence and urban-rural residence), and also on the problems of accessibility and affordability affecting service use. ${ }^{1}$ The analysis focuses on six public infrastructure services (electricity, gas, water, fixed telephone, mobile telephone and internet) for three large EU countries (the UK, Spain and Italy), where comparable information both for RP and SP is available, as explained below in the third section.

This paper makes two main contributions. First, it performs for the first time - to the best of the authors' knowledge - a general analysis of differences in expenditure on public infrastructure services from a territorial dimension (considering both regional and urban-rural residence) in the EU context. Second, it analyses the with problems of affordability and/or accessibility. Results detect frequent problems of accessibility or affordability (or both) for internet and gas, which

affect residents in territories characterized by low population density and low gross domestic product (GDP) per capita. These problems may disadvantage residents in these territories if substitutable services are not available, presenting challenges for territorial cohesion. In contrast, these problems are rarely observed for water and electricity.

The paper is organized as follows. The second section sets out the approach to territorial cohesion as regards public infrastructure services mobilized in the paper, describes policy issues and debates on the regulation of these services from a territorial perspective, and the state of the art on service analysis from a territorial dimension. The third section explains the hypotheses, data and empirical approach used. The fourth section describes the estimated effects of the territorial dimensions under analysis on expenditure and on satisfaction with service access and price. The fifth section concludes by interpreting how the results present evidence of challenges for territorial cohesion and discusses their policy implications.

\section{PUBLIC INFRASTRUCTURE SERVICES FROM A TERRITORIAL PERSPECTIVE}

Public infrastructure services and territorial cohesion

'Territorial cohesion' is a political concept that has been on the agenda of the European authorities since the 1990s. Scholars coincide that the definition of this concept is still somewhat vague (MEDEIROS 2012; RauHut and Ludlow, 2013; COLOMB and SANTINHA, 2014). The approach to territorial cohesion adopted here takes as a starting point the definition as found in the Territorial Agenda of the European Union 2020 (EU, 2011), which states territorial cohesion is

a set of principles for harmonious, balanced, efficient, sustainable territorial development. It enables equal opportunities for citizens and enterprises, wherever they are located, to make the most of their territorial potentials. Territorial cohesion reinforces the principle of solidarity to promote convergence between the economies of better-off territories and those whose development is lagging behind.

SANTINHA (2014, p. 91) advanced a more precise definition of territorial cohesion as derived from EU discourse and policy, which he summarized as having three main objectives: (1) the harmonious development of territories, including diminishing disparities among them; (2) the consideration of territorial diversity and complementarities as a potential for development; and (3) the interaction and coordination of different territorial and sectoral policies, and policy-makers in a territorial approach. This paper adopts this approach. Furthermore, ESPON (2013) can be used to connect these 
three broader objectives to three specific policy ambitions pursued by the EU as regards public infrastructure services and territorial cohesion: (1) to promote equality of opportunities through a more balanced access to services, whilst drawing attention to local specificities ('Rebalancing principle'); (2), to take advantage of services for increasing territorial competitiveness, adopting sustainable development strategies ('Growth and development principle'); and (3), to consider territory to integrate policies and their objectives in a place-based approach ('Territorially oriented principle'). The empirical research conducted in this paper focuses primarily on the first of these policy ambitions (the 'Rebalancing principle'). Hence, following Molde (2007),

345 this paper analyses whether differences in public infrastructure service provision associated with residence constitute a disadvantage to those citizens who live there. Whether or not services are substitutable is an important consideration when evaluating whether differences in the provision of services imply disadvantages for residents, as will be explained below in the third section. Finally, all three ESPON (2013) policy ambitions are taken into account when the results are interpreted and conclusions are presented.

\section{Reforming public infrastructure services: a territorial perspective}

Significant reform of public infrastructure services across the EU from the 1980s sparked debate as to the consequences of these changes from a territorial perspective. WISHLADE (2008) observed how EU competition policies - which were at the core of these market-oriented reforms - triggered concern about the consequences for regional policies and cohesion. From the 1980s onwards, an increasing number of public infrastructure services became subject to Single Market rules, in particular through exposure to sectoral policies to liberalize, deregulate and introduce competition (CLIFTON et al., 2010, Warner and Clifton, 2014). Meanwhile, most EU governments privatized public infrastructure services, albeit unevenly, from the 1990s. Of the six services under analysis, reforms were the most far-reaching in telecommunications, slower, but significant, in energy services, and slowest in the water sector, where significant inter- and intra-country differences remain (Bel et al., 2010; HAll and Lobina, 2010; BeL and WARNER, 2015).

Scholars noted that market-oriented reforms may change the behaviour of utilities providing public infrastructure services (SCLAR, 2015). Privatization, liberalization and competition could lead firms to prioritize profit-making at the expense of other goals, such as accessibility and affordability (VAN DE WALLE, 2006). A major concern was that citizens living in territories where service provision was not deemed profitable may be excluded from service provision or of bearing the extra costs (Molle, 2007; VAN De Walle, 2009; Clifton and Díaz-Fuentes, 2010). Service accessibility and/or affordability in remote and rural areas could potentially deteriorate with reform, reflecting potential tensions between Single Market rules and territorial cohesion objectives (COUNCIL OF European Municipalities and Regions (CEMR), 2009; Medeiros, 2012; Colomb and SANTINHA, 2014).

The regulation of public infrastructure services aimed to address these concerns from the citizens' perspective. Historically, the place of public infrastructure services as regards citizens' rights varied across the EU: in France, Italy and Spain, legislation traditionally guaranteed citizens' rights to these services, while in the Netherlands and the UK, specific obligations regarding service accessibility, quality and continuity existed, albeit not in a constitution. Attempts to set up an EU-wide Charter of citizens' rights to SGEI failed during the 2000s (Clifton et al., 2005). Thus, citizens' rights to these services are still mostly guaranteed by national authorities as PSO, according to domestic criteria (EUROpeAn Centre of Employers and Enterprises Providing Public Services (CEEP), 2010).

Public infrastructure services reform had a varied impact across Italy, Spain and the UK. All three countries were enthusiastic adopters of market-oriented reform, but differences remained as regards the timing and extent of reform by sector, as well as the historical and institutional configuration of public infrastructure services (Millward, 2005; Bel et al., 2006; Clifton et al., 2006). Whilst the UK privatized and liberalized early on, from the 1980s, Spain and Italy liberalized energy and telecommunications somewhat later, during the 1990s, to fulfil EU directives. In Italy and Spain, public infrastructure services were legally encompassed under the concept of 'public service' (COSTAS, 2007). This implied guaranteeing universal provision of a certain minimum provision of these services, with the aim of promoting equal access to services, including citizens with lower economic resources and rural residents. In parallel to market-oriented reforms, regulatory priorities shifted to productive efficiency, whilst technological improvements and new services emerged, particularly in the telecommunications sector. In Spain, legislative changes accompanying liberalization led to the substitution of the concept of 'public service' by the PSO, according to EU terminology. In Italy, EU terminology was introduced to distinguish between social and commercial services, while in the UK SGEI terminology was not incorporated into official legislation (CEEP, 2010). Nevertheless, UK legislation recognized infrastructure services as being important and regulation essentially consisted of defining services and guaranteeing their provision. The UK also pioneered specific policies to support so-called vulnerable consumers (including residents in rural areas) by improving the information available to them and reducing the costs of switching (OFFICE OF GAS AND ELECtricity MARKets (OFGEM), 2012). Processes of 
decentralization or devolution undertaken by governments in these three countries did not significantly affect way in which public infrastructure services were regulated. However, in the UK, some policies were transferred to devolved governments (such as policies for rural areas in Scotland and Wales), leading to regulatory divergences with respect to England (KEATING and Stevenson, 2006).

The main theoretical and policy issues on public infrastructure services regulation from a territorial perspective are described in detail in Appendix A in the Supplementary data online, including the main characteristics of each service, their regulatory framework both at country and EU levels, and the main challenges for 455 territorial cohesion as derived from EU policy documents and secondary literature.

Public infrastructure services and the territorial dimension: existing evidence

The main findings from the literature on public infrastructure services from a territorial perspective are now summarized. Key sources include the European Atlas of Services of General Interest (BBSR, 2013) and the work 465 developed by the programme ESPON (ESPON, 2007b; 2013).

BBSR (2013) analyses from the supply side regional differences as regards services of general interest (SGI), a term the EU uses to refer to all public services, includ-

470 ing SGEI. It focuses on the availability of suppliers, number of providers and service price. Using a set of indicators, BBSR (2013) obtains a regional score for SGEI provision and finds that regions at the core of the EU had higher results than peripheral regions. This result is pertinent for the regions of the three countries under analysis. In addition, the score is positively correlated with population density and GDP per capita and negatively correlated with the share of rural areas in the region.

Much of the existing research literature on public infrastructure services from a territorial perspective focuses on the use of information and communications technologies (ICT). ICT use is broadly considered to impact positively economic and territorial development (SURIÑACH et al., 2007; SUBACCHI et al., 2014), particularly the internet. Hence, the EC included universal high-speed broadband coverage by 2020 as a key objective for the Digital Agenda strategy (EC, 2010). ESPON Project 1.2.3 on Information Society (ESPON, 2007b) provides useful evidence in this regard. This project analyses the availability, use and development of ICT at the regional level, including indicators on telecommunications, particularly the internet. Results show significant differences between countries, but also between bithin countries, with core areas generally in better position than remote and peripheral regions. Among the main factors explaining territorial disparities, ESPON (2007b) identifies the settlement structure, the primacy of capital cities, the development of technical infrastructure in areas with low population density, the diffusion period for new technologies (disparities tend to reduce as the period of availability of a technology increases), cultural differences and adaptation barriers, and the socio-economic structure of the population. Additional evidence is provided by BILlón et al. (2008), who analyse disparities among EU regions as regards internet adoption (which they find to be greater than economic disparities). These authors explain these differences by factors such as regional GDP per capita, the stock of human capital and population density.

Many scholars, mostly analysing ICT, find the urbanrural divide matters in public infrastructure services provision. This is exemplified by the 'digital divide' in the use of the internet (EC, 2008). Further evidence on the urban-rural divide can be found in the ESPON project (ESPON, 2013). Regional indicators of public infrastructure services are analysed, including transport, electricity, water and telecommunications. This project also analyses service accessibility, affordability and quality from case studies representing nine European regions. ESPON (2013) observes that the type of territory generally determines accessibility, whilst a strong polarization exists between rural and urban areas. As regards affordability, a dispersed settlement and low population density make the installation of network infrastructure more costly. Therefore, areas with concentrated demand benefit from greater availability, accessibility, quality and affordability of SGI than remote, rural and, in general, areas with lower population density, presenting a challenge for territorial cohesion. ESPON (2013) promotes the use of local specific factors, rather than universal solutions, to address these problems.

These studies coincide that there is a lack of empirical analysis on public infrastructure service affordability and accessibility adopting a territorial perspective from the demand side (BBSR, 2013; Breuer and Milbert, 2013). European regulatory policies on these services have started to analyse the demand side, particularly as regards attaining a better understanding of how consumer-related factors condition decisions and attitudes towards these services (JiLKe, 2015). Previously, it had been assumed that supply-side reforms would be sufficient to benefit consumers. Recently, however, the EC has recognized the insufficiencies of competition policies alone and, therefore, is seeking its integration with new policies based on consumers' perspective (Clifton et al., 2014).

STRAUSS (2008) argued that evidence should be incorporated from the consumers' perspective into regional science in order to improve the integration of economic and geographic analysis through greater attention paid to the social context that conditions decision-making. As part of the emerging interest in evaluating satisfaction, the territorial dimension is 
essential, since it permits scholars to incorporate territory as an explanatory factor of decisions and perceptions. However, the most significant contributions on satisfaction have not specifically focused on the territorial perspective. Moreover, in the small number of contributions that have considered territory, analysis is usually limited to one sector and/or one country. In broader analyses of satisfaction with public infrastructure services from the citizen perspective, FIORIO et al. (2007) and FIORIO and FLORIO (2011) observed, within the EU, a relation between higher country population density and greater satisfaction, stressing the complexity of the economic, institutional and social environment as a determinant in these opinions. Miniaci et al. (2008) highlighted the impact of geographic and social differences between regions in Italy for consumption patterns of electricity, gas and water. Regarding consumers' behaviour, GiUlietTi et al. (2005) found that, in the UK, residents in areas of low population density were less likely to switch gas supplier, which they explained as being due to search cost factors due to the policies of the providers. The approach by STRAUSS (2008), to integrate economic and geographical analysis better, can also be applied when analysing citizens' decisions and satisfaction as regards public infrastructure services depending on their place of residence.

\section{DATA AND EMPIRICAL APPROACH}

The empirical approach used here is based on the combined analysis of citizens' RP and SP. RP, resulting from observable decisions in the markets, provide indicators broadly considered to be objective (VAN DOOREN and VAN DE WALLE, 2008). SP consist of individuals' self-assessment of their perceptions towards services. SP permit the analysis of aspects that RP alone are unable to detect, such as the reasons for lower or nonexistent consumption or the satisfaction obtained. Public infrastructure services often operate in quasi-, rather than in competitive, markets: the exit and change of providers are not easy, hence RP do not always reflect citizens' real preferences (CosTAs, 2007). Consequently, voice (satisfaction) is an important question to consider. This approach allows for the incorporation of the spatial dimension into an evaluation of satisfaction, following CORRADO et al. (2013). Thus, as suggested by FIORIO and FLORIO (2011), both RP and SP provide a useful way to evaluate public infrastructure services regulation, in this case from a territorial perspective. Combining their analysis constitutes an innovative approach to this topic (WHITEHEAD et al., 2008).

The hypotheses are based on the approach to territorial cohesion by MoLle (2007), oriented to equality of opportunities derived from service access. Differences among territories as regards service provision and use may exist as a result of territorial diversity: these are considered a concern for territorial cohesion when these differences are associated with disadvantages for residents, as this may signal a lack of equality of opportunities. Territorial differences in service use are analysed using information about expenditure on services (RP). To analyse whether these differences constitute disadvantages, these are contrasted with information about citizens' satisfaction with access to (accessibility) and price of (affordability) the services (SP) ₹ the most important issues regarding public infrastructure regulation from a territorial perspective (ESPON, 2013).

The territorial analysis here focuses on two dimensions: region of residence and urban-rural residence. As regards the former, this paper enquires to what extent differences among regions exist as regards expenditure on services and, in the case where there are differences, whether these are associated with disadvantages as regards problems of accessibility and affordability. Thus, the first hypothesis is formulated as follows:

Hypothesis 1. Regional differences exist in expenditure on public infrastructure services, and in satisfaction with service access and price.

Additionally, the paper analyses whether regional characteristics contribute to explaining these differences, by testing the following hypothesis:

Hypothesis 2. Regional characteristics influence expenditure on public infrastructure services, and satisfaction with service access and price.

As regards the urban-rural dimension, empirical evidence suggests that a polarization between urban and rural areas may exist in the provision of certain services, which may present a challenge for territorial cohesion (EC, 2008; ESPON, 2013). As explained above in the second section, from both theoretical and empirical viewpoints (ESPON, 2013), rural residents, where a lower population density may make service provision less profitable, may be more likely to be disadvantaged as regards service provision. These residents can be totally or partly excluded, leading to problems of accessibility, or their bearing of (some of) the extra costs, leading to problems of affordability. ${ }^{2}$ To contrast whether differences between urban and rural areas exist in the use of services, the next hypothesis is formulated:

Hypothesis 3. Urban-rural residence affects expenditure on public infrastructure services.

To assess - in the case where there are differences whether these differences are associated with disadvantages, respectively, as regards accessibility and affordability, the following hypotheses are formulated:

Hypothesis 4. Those living in rural areas are less likely to be satisfied with access to public infrastructure services.

Hypothesis 5. Those living in rural areas are less likely to be satisfied with the price of public infrastructure services. 
The information on RP is obtained from HBS microdata for 2006. These are national surveys that collect information on households' expenditure by categories of goods and services, as well as on households' socioeconomic characteristics. In most EU countries, these surveys contain disclosive information. For the purposes of this paper, data were obtained for the UK (ONS, 2006), Spain (INE, 2006) and Italy (ISTAT, 2006). These are large surveys $(6645,19435$ and 23639 observations, respectively), representing a total population of 163.4 million inhabitants in 2006. In the estimations, the logarithm of households' expenditure on electricity, gas, water and telecommunications, ${ }^{3}$ in euros per year, is considered as the dependent variable.

The sources for SP are microdata from the Special Eurobarometer 260 on Services of General Interest, corresponding to 2006 (EC, 2007). This is the most recent Eurobarometer specifically dedicated to public infrastructure services. It provides information on EU-25 citizens' perceptions regarding key aspects of the provision of these services, including use, accessibility and affordability. This paper uses the subsamples corresponding to the three countries where information for RP is available: the UK, Spain and Italy (1337, 1006 and 1024 observations, respectively). In the estimations, for each service (electricity, gas, water, fixed telephone, mobile telephone and internet) two elements are considered as dependent variables. Firstly, the probability of satisfaction with access, from a binary variable that 690 equals 1 if the individual states access to the service is 'easy'; and 0 otherwise. Secondly, the probability of satisfaction with the price, from a binary variable that equals 1 when the individual states the service is 'affordable'; and 0 otherwise.

With respect to the independent variables, the analysis focuses on those related to the place of residence:

- Country. The binary variables SPAIN, and ITALY, reflect the effects associated with living in these countries, in relation to the UK (reference category).

- Region. NUTS $-1^{4}$ are considered as the level of territorial disaggregation, as this is the most disaggregated level where information is available in both Eurobarometer and HBSs. This variable reflects the effect of living in each NUTS-1 with respect to that region used as a reference category in each country, which is that with the highest GDP per capita and the highest population density in the country, according to EUROSTAT data: London in the UK, Madrid in Spain and Nordovest in Italy.

For a further explanation of results at the regional level, in additional estimations, independent variables representing regional characteristics (also at the NUTS-1 level) are included instead of regional 715 dummies (for the full results, see Appendix B in the Supplementary data online). These are: (1) GDP per capita (in purchasing power parity (PPP)); (2) population density; (3) degrees of cold temperature in winter, using the average of actual heating degree-days in January, February and December; and (4) degrees of warm temperature in summer, using the average of the temperature in the warmest month in the two biggest cities where information is available. Information is obtained from EUROSTAT (2006), corresponding to 2006, except for the fourth variable, which is from EUROSTAT (2008) and corresponds to the average of 2004 and 2008.

- Rural residence, through a binary variable (RURAL), equalling 1 if the respondent lives in a rural area; and 0 otherwise. The definition of 'rural area' is based on the information provided in the surveys, according to the criteria used in each territory. In Eurobarometer, the variable is derived from the respondents' own definition of their place of residence, using a value of 1 for those who state they live in a 'rural area or village'; and 0 otherwise.

The variable $R U R A L$ is analysed by considering the interaction effect with the country of residence. This enables correction for any disparities by country in the definition of the variable, and to analyse separately between countries the effect of living in a rural area on the dependent variables.

Control variables commonly available both for RP and SP are also introduced: (1) household size, using the number of members and this variable squared for $\mathrm{RP}$, and binary variables representing the number of members for SP; (2) age, using variables corresponding to intervals of under 35, between 50 and 64, and over 64 years (the reference category being between 35 and 49); (3) housing occupancy status, differentiating nonowners and owners; and (4) for RP, household annual-equivalent expenditure (in logarithms), adjusted by household size through the modified Organisation for Economic Co-operation and Development (OECD) scale, to correct for the income effect on expenditure on services. The estimations incorporate population weights from the surveys, providing results representative of the whole population of the countries under analysis.

With respect to $\mathrm{RP}$, the following estimation is carried out for each service:

$$
\ln \left(\mathrm{EXP}_{i j}\right)=f\left(x_{i}\right)=f\left(C_{i}, N_{i}, R_{i}^{*} C_{i}, Z_{i}^{R}\right)
$$

where $E X P_{i j}$ is the expenditure of household $i$ on service $j ; j$ is (electricity, gas, water, telecommunications); $C_{i}$ is the country of residence of $i_{i} N_{i}$ is the region (NUTS-1) of residence of $i, R_{i}$ is the residence in a rural area; and $Z_{i}^{R}$ is the yector of control variables.

To test the effects of regional characteristics, an additional estimation of the following form is carried out for each service:

$$
\ln \left(\mathrm{EXP}_{i j}\right)=f\left(x_{i}\right)=f\left(C_{i}, Z_{i}^{N}, R_{i}^{*} C_{i}, Z_{i}^{R}\right)
$$


where $Z_{i}^{N}$ is the vector of characteristics of region of residence of $i$.

Regarding SP, assuming that the random disturbance follows a normal standard distribution $u_{i}\left(0, \sigma^{2}\right)$, the effects of the independent variables on the probability of stated satisfaction with access and price is estimated, for each service $j$, through two probit models of the form:

$$
\begin{aligned}
& P\left(\operatorname{Sat} A_{i j}=1\right)=\Phi\left(x_{i}\right)=\Phi\left(C_{i}, N_{i}, R_{i}^{*} C_{i}, Z_{i}^{S}\right) \\
& P\left(\operatorname{Sat} P_{i j}=1\right)=\Phi\left(x_{i}\right)=\Phi\left(C_{i}, N_{i}, R_{i}^{*} C_{i}, Z_{i}^{S}\right)
\end{aligned}
$$

where $\operatorname{Sat} A_{i j}$ is the satisfaction with access to service $j$ by individual $i ; \operatorname{Sat} P_{i j}$ is the satisfaction with the price of service $j$ by individual $i, j$ is (electricity, gas, water, fixed phone, mobile phone, internet); $C_{i}$ is the country of residence of $i, N_{i}$ is the region (NUTS-1) of residence of $i, R_{i}$ is the residence in a rural area; and $Z_{i}^{S}$ is the vector of control variables.

Whilst the effects of regional characteristics are estimated, for each service $j$, from two additional probit models of the following form:

$$
\begin{aligned}
& P\left(\operatorname{Sat} A_{i j}=1\right)=\Phi\left(x_{i}\right)=\Phi\left(C_{i}, Z_{i}^{N}, R_{i}^{*} C_{i}, Z_{i}^{S}\right) \\
& P\left(\operatorname{Sat} P_{i j}=1\right)=\Phi\left(x_{i}\right)=\Phi\left(C_{i}, Z_{i}^{N}, R_{i}^{*} C_{i}, Z_{i}^{S}\right)
\end{aligned}
$$

where $Z_{i}^{N}$ is the vector of characteristics of region of residence of $i$.

Results are contrasted through a combined analysis of RP and SP (WhiteheAd et al., 2008). To do so, RP are first analysed, considering that expenditure on a service is the product of the quantity consumed $(X)$ and the unit price $(P)$. Thus, a different level of expenditure on a service in a particular territory may be explained by three different reasons, which can be inferred from SP:

- Consumption of a quantity $(X)$ of the service lower than that desired due to access problems, leading to lower expenditure. This is inferred from estimations on satisfaction with access. Observing less satisfaction with access to a service in a territory, associated with lower expenditure on the service, would suggest evidence of a lack of equal service access (accessibility). The availability of a substitute services is taken into account when evaluating if this might constitute a disadvantage for residents.

- A different unit price $(P)$. This is inferred from estimations on satisfaction with price. A higher unit price leads to greater expenditure if the quantity consumed $(X)$ does not change. However, if a higher unit price negatively affects the demand, this may lower the quantity consumed, and thus, even to lower expenditure. In both cases, observing less satisfaction with the price of a service in a territory, associated with different service expenditure, would suggest there is evidence of a problem regarding service availability in equal price conditions (affordability). Again, the availability of substitutable services is considered when evaluating whether this might constitute a concern for territorial cohesion.

- Consumption of a different quantity $(X)$ of the service due to distinct preferences or needs, leading to different expenditure. If statistically significant differences in satisfaction with access to and/or price of a service are not detected in a territory, this explanation for differences in expenditure may apply. Here, no challenge for territorial cohesion is identified.

\section{RESULTS}

Table 1 summarizes results from estimations on expenditure on services (RP). Tables 2 and 3 summarize results from estimations on satisfaction with access to and price of services, respectively (SP). Estimates indicate the marginal effects associated with each independent variable $k$, defined as the expected changes in the dependent variables generated by a unitary increase in $k$. The results are organized by differentiating the regional differences and urban/rural differences. Full results of the estimations, including effects associated to regional characteristics, are shown in Appendix B in the Supplementary data online. The overall findings and the associated potential challenges for territorial cohesion are summarized in Appendix $\mathrm{C}$ also in the Supplementary data online.

\section{Regional differences}

Revealed preferences $(R P)$. Significant regional differences exist in expenditure on the six services, confirming that territory matters for service use (Table 1). For electricity and gas, regional climate characteristics (temperature in both summer and winter) help explain these differences due to their role in summer cooling and winter heating. Furthermore, expenditure on electricity is lower in regions with higher GDP per capita and higher population density, whereas expenditure on gas is higher in regions with higher population density. Expenditure on gas is sharply lower in Northern Ireland and Canarias, where the use of gas is less extended. As regards water, greater expenditure is particularly associated with regions characterized by warmer temperatures in summer. Expenditure on water is also greater as regional GDP per capita increases, and lower as regional population density increases. Expenditure on water is non-existent in Northern Ireland, as there was no direct payment for the service. Expenditure on telecommunications is particularly higher in regions with higher GDP per capita. 
Table 1. Effects estimated on expenditure on services

\begin{tabular}{|c|c|c|c|c|c|}
\hline & & Electricity & Gas & Water & Telecom \\
\hline \multirow{23}{*}{ NUTS-1 } & Constant term & 0.059 & $-1.654 * * *$ & $1.968 * * *$ & $-1.647 * * *$ \\
\hline & UKINGDOM & & & & \\
\hline & NORTHWEST & $0.288 * *$ & $0.229 *$ & $0.149 * * *$ & $-0.503 * * *$ \\
\hline & NEASTEYORKS & $0.287 * *$ & $0.218^{*}$ & $0.128 * * *$ & $-0.356 * * *$ \\
\hline & MIDLANDS & $0.291 * * *$ & $0.300 * *$ & $0.145 * * *$ & $-0.213 * * *$ \\
\hline & $\begin{array}{l}\text { EASTENGLAND } \\
\text { LONDON }\end{array}$ & $0.433 * * *$ & -0.160 & $0.159 * * *$ & $-0.192 * *$ \\
\hline & SOUTHEAST & $0.410 * * *$ & 0.040 & $0.091 * *$ & $-0.316^{* * *}$ \\
\hline & SOUTHWEST & $0.521 * * *$ & $-0.282^{*}$ & $0.137 * *$ & $-0.188 * *$ \\
\hline & WALES & $0.522 * * *$ & 0.221 & $0.267 * * *$ & $-0.435 * * *$ \\
\hline & SCOTLAND & $0.355 * * *$ & $-0.297 * *$ & -0.024 & $-0.151 *$ \\
\hline & NIRELAND & $0.382 * * *$ & $-4.382 * * *$ & $-5.862 * * *$ & -0.096 \\
\hline & SPAIN & $0.410^{* * *}$ & $-0.822 * * *$ & $-0.953 * * *$ & $-0.126 *$ \\
\hline & NOROESTE & -0.040 & $-1.260 * * *$ & $-0.989 * * *$ & -0.068 \\
\hline & $\begin{array}{l}\text { NORESTE } \\
\text { MADRID }\end{array}$ & -0.032 & $1.126 * * *$ & $0.597 * * *$ & -0.067 \\
\hline & CENTROSPA & $0.076^{* *}$ & $-1.490 * * *$ & $-0.521 * * *$ & $-0.170 * * *$ \\
\hline & ESTE & $0.067 *$ & $-1.208 * * *$ & 0.047 & $-0.164 * * *$ \\
\hline & $\hat{S} U R$ & $0.131 * * *$ & $-2.114 * * *$ & -0.005 & $-0.207 * * *$ \\
\hline & CANARIAS & $-0.222 * * *$ & $-3.575 * * *$ & $0.351 * * *$ & -0.074 \\
\hline & $\begin{array}{l}\text { ITALY } \\
\text { NORDOVEST }\end{array}$ & $0.461 * * *$ & $0.472 * * *$ & $-3,075^{* * *}$ & $-0.362 * * *$ \\
\hline & NORDEST & $0.084 * * *$ & -0.038 & $0.909 * * *$ & 0.025 \\
\hline & CENTROITA & $0.114 * * *$ & 0.003 & $0.472 * * *$ & $0.097 * * *$ \\
\hline & $\hat{S} U D$ & $0.285 * * *$ & $-0.299 * * *$ & $0.427 * * *$ & $-0.089 * * *$ \\
\hline & ISOLE & $0.517 * * *$ & $0.538 * * *$ & 0.100 & -0.046 \\
\hline \multirow[t]{3}{*}{ Rural residence } & RURAL*UK & $0.130 *$ & $-2.490 * * *$ & $-0.378 * * *$ & $-0.093 *$ \\
\hline & $R U R A L^{*} S P A$ & -0.035 & $-0.847 * * *$ & $-0.650 * * *$ & $-0.227 * * *$ \\
\hline & $\hat{R} U R A L * \hat{I T A}$ & $0.075 * * *$ & $-0.422 * * *$ & 0.045 & $-0.079 * * *$ \\
\hline \multirow[t]{2}{*}{ Household size } & NMEMBERS & $0.310 * * *$ & $0.475 * * *$ & $0.323^{* * *}$ & $0.526 * * *$ \\
\hline & $\hat{N} M E M B E R S^{2}$ & $-0.018 * * *$ & $-0.036 * * *$ & $-0.027 * * *$ & $-0.040 * * *$ \\
\hline \multirow[t]{3}{*}{ Age } & $<35$ & $-0.111 * * *$ & $-0.129 * *$ & $-0.107 * * *$ & -0.013 \\
\hline & $50-64$ & $0.199 * * *$ & $0.179 * * *$ & $0.152 * * *$ & $0.086 * * *$ \\
\hline & $>64$ & $0.296 * * *$ & $0.327 * * *$ & $0.207^{* * *} *$ & $-0.066 * * *$ \\
\hline Housing tenure & NOPROP & $-0.432 * * *$ & $-0.602 * * *$ & $-0.093 * * *$ & $-0.128 * * *$ \\
\hline Income & $\ln E X P E N D$ eq & $0.484 * * *$ & $0.628 * * *$ & $0.333 * * *$ & $0.731 * * *$ \\
\hline$N$ & & 49719 & 49719 & 49719 & 49719 \\
\hline$F$ & & 79.19 & 577.86 & $4,662.46$ & 138.79 \\
\hline$P>\mathrm{chi}^{2}$ & & 0.000 & 0.000 & 0.000 & 0.000 \\
\hline
\end{tabular}

Note: *Statistical significance at $10 \%$; **tatistical significance at $5 \%$; ***statistical significance at $1 \%$.

Sources: Author calculations based on Office fOR National Statistics (ONS) (2006), Instituto Nacional De EstadÖStica (INE) (2006) and Instituto Nazionale di Statistica (ISTAT) (2006).

Stated preferences $(S P)$. Satisfaction with service access is generally lower in the regions of Noreste in Spain and Sud and Isole in Italy (Table 2). Beyond these three cases, regional problems of accessibility are concentrated in two services: gas and the internet. As regards gas, in several regions (Northern Ireland, Scotland and Southwest in the UK; Canarias, Noreste and Noroeste in Spain; and Isole and Sud in Italy) lower satisfaction with access combined with lower expenditure on this service reflect problems of accessibility. In many of these regions, population density is below the national average. Low population density is a factor associated with regional problems of accessibility to gas: this variable negatively influences satisfaction with access, and expenditure on this service. As for the internet, satisfaction with access is particularly low in Italy (especially in Isole), as well as in Wales, Scotland and Northern
Ireland (UK), and Noroeste (Spain). GDP per capita in most of these regions is below the national average. Low GDP per capita is associated with regional problems of accessibility to the internet, as it negatively influences satisfaction with service access.

As to satisfaction with service price, again, certain regions are systematically associated with poorer results, especially Isole, Sud and Centro in Italy (Table 3). Additionally, satisfaction with the price of gas is particularly low in Northern Ireland and Canarias. In contrast, citizens in Scotland are more satisfied with the price of water, whilst expenditure is lower than in most other UK regions. This may be associated with differences in the priorities of regulatory policies, which were reinforced by the devolution process. The Scottish water regulatory regime (basically, a public monopoly, in contrast to the system of private 
Table 2. Marginal effects estimated on satisfaction with access to services

$\begin{array}{ll} & >4 \text { PERSON } \\ \text { Age } & <35 \\ & 50-64 \\ & >64 \\ \text { Housing tenure } & \text { NOPROP } \\ \hat{N} & \\ \text { Wald } \mathrm{chi}^{2} & \\ \text { Prob }>\mathrm{chi}^{2} & \end{array}$

Electricity

0.032
0.028
-0.038
-0.134
$0.051 * *$
-0.019
-0.048
0.029
0.007
0.021
-0.138
$-0.456 * * *$
-0.079

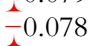

$-0.043$

$-0.030$

$-0.231 * * *$

$-0.004$

0.018

$-0.020$

$-0.039$

$-0.029$

0.005

$-0.016$

$-0.013$

$-0.018$

$-0.011$

$-0.032$

$-0.012$

0.013

$-0.007$

$-0.002$

3,367

334.21

0.000

0.011

$-0.059$

$-0.012$

-0.163 *

$-0.030$

$-0.039$

$-0.067 *$

$-0.171 *$

0.060 *

$-0.024$

0.002

0.029

$-0.024$

$-0.024$

$-0.025$

$-0.002$

452.23

0.000

Gas

Water

$0.119 * *$

$-0.340 * * *$

0.047

$-0.015$

-0.015
-0.083

$0.248 * *$

$-0.276 * *$

$-0.658^{* * * *}$

$-0.224 * * *$

$-0.156 * *$

$-0.226 * * *$

$0.066^{*}$

$0.097 * * *$

$-0.418 * * *$

$-0.284 * * *$

$-0.026$

-0.026
-0.080

$-0.062$

$0.049^{*}$

$0.051 * * *$

$-0.012$

$-0.066$

-0.312 ***

0.025

0.027

$0.049 * *$
$0.049 *$

$-0.195 * * *$

$-0.039$

$-0.236 * * *$

$-0.182 * * *$

$-0.003$

$-0.006$

0.011

$-0.026$

$-0.063 *$

0.014

$-0.053$

$-0.021$

0.009

0.004

0.004

$-0.050^{*}$

-0.003
0.016

0.004

3,367

0.003

3,367

327.17

0.000
Fixed phone

Mobile phone

Internet

\begin{tabular}{|c|c|}
\hline 0.033 & 0.055 \\
\hline-0.047 & 0.013 \\
\hline 0.023 & -0.020 \\
\hline 0.007 & -0.058 \\
\hline-0.027 & -0.063 \\
\hline 0.059 & 0.068 \\
\hline-0.025 & -0.039 \\
\hline 0.021 & -0.033 \\
\hline-0.018 & 0.015 \\
\hline 0.034 & 0.063 \\
\hline-0.137 & -0.061 \\
\hline-0.062 & -0.005 \\
\hline-0.088 & -0.028 \\
\hline-0.071 & -0.053 \\
\hline-0.058 & 0.025 \\
\hline-0.033 & -0.074 \\
\hline$-0.178 * *$ & $-0.131 * * *$ \\
\hline $0.038 * *$ & $0.051 *$ \\
\hline $0.040 * *$ & 0.044 \\
\hline$-0.108 * * *$ & $-0.103 * *$ \\
\hline 0.156 *** & $-0.218 * * *$ \\
\hline 0.016 & -0.020 \\
\hline 0.003 & -0.046 \\
\hline-0.039 & -0.044 \\
\hline-0.004 & $-0.036^{*}$ \\
\hline 0.001 & 0.007 \\
\hline 0.017 & 0.003 \\
\hline-0.011 & -0.019 \\
\hline-0.002 & 0.026 \\
\hline 0.004 & $-0.048 * *$ \\
\hline$-0.053 * *$ & $-0.298 * * *$ \\
\hline $0.047 * * *$ & $0.031 *$ \\
\hline 3,367 & 3,367 \\
\hline 374.55 & 359.81 \\
\hline 0.000 & 0.000 \\
\hline
\end{tabular}

0.040

$-0.064$

$-0.089$

$-0.078$

0.041

$0.107 *$

$-0.168 *$

$-0.157 * *$

0.110 *

0.011

$-0.275^{* * * *}$

$-0.093$

$-0.050$

0.023

$-0.004$

$-0.009$

$0.172 * * *$

0.048

$-0.045$

$-0.153 * * *$

$-0.018$

$-0.076 *$

$-0.106 * *$

$-0.031$

$0.043 *$

$0.091 * * *$

$0.058^{*}$

$0.091 * * *$

$-0.099 * * *$

$-0.406 * * *$

$-0.076^{* * *}$

3,367

527.79

0.000
$-0.383 * * *$

1050

Note: *Statistical significance at $10 \%$; * statistical significance at $5 \%$; ***statistical significance at $1 \%$.

Source: Authors' own calculations based on EuropeAn COMMISSION (2007).

1030

monopolies in England and Wales) and its pricing policies (charges based on the council tax band for each household) boast relatively positive results in terms of citizen satisfaction (ScOtTISH WATER, 2013). In Northern Ireland, despite the fact that water was not paid for directly (NORTHERN IRELAND WATER, 2013), price satisfaction is similar to other UK regions. On the other hand, as regards regional characteristics, satisfaction with service price is generally higher (except for gas) as regional GDP per capita increases, reflecting that further difficulties for service affordability may exist in the poorer regions. In contrast, low population density is not associated with difficulties as regards service affordability at the regional level. Finally, cold temperatures in the winter are associated with greater satisfaction with service price (especially for gas). In regions where temperature in winter is colder than average, residents may perceive the price to be paid for the service as more satisfactory, as they are particularly dependent on this service.

Urban/rural differences

1090

Revealed preferences $(R P)$. Significant differences exist between urban and rural areas as regards service expenditure, so the urban-rural divide also matters for service use. In particular, expenditure on gas is much lower in rural areas in all three countries, especially in the UK. Also, expenditure on telecommunications is lower in rural areas in all three countries, especially in Spain, although these differences are not as intense as they are for gas. Expenditure on electricity in rural areas is slightly higher in the UK and Italy, but not in Spain, whilst expenditure on water in rural areas is lower in the UK and Spain, but not in Italy. 
Table 3. Marginal effects estimated on satisfaction with the price of services

1105

1110

Age

Electricity

Gas

$0.133 * * *$
0.069
0.064
0.062
$0.132 * * *$
$0.130 * *$
0.038
$0.095 *$
$0.155^{* * *}$
-0.030
$-0.151 * *$
$-0.162 * *$

$0.199 * * *$

NORTHWEST

NEASTEYORKS

MIDLANDS

EASTENGLAND

LONDON

SOUTHEAST

SOUTHWEST

WALES

SCOTLAND

NIRELAND

$\widehat{S P A I N}$

NOROESTE

NORESTE

MADRID

CENTROSPA

ESTE

SUR

CANARIAS

ITALY

NORDOVEST

NORDEST

CENTROITA

SUD

ISOLE

Rural residence

Household size

Housing tenure

RURAL*UK

RURAL*SPA

RURAL*ITA

IPERSON

3PERSON

APERSON

IPERSON

$<35$

50-64

65-74

NOPROP

Note: *statistical significance at $10 \% ; * *$ statistical significance at $5 \% ; * * *$ statistical significance at $1 \%$.

Source: Authors' own calculations based on EuropeAn COMMISSION (2007).

Stated preferences (SP). When evaluating whether differences identified in service use are associated with disadvantages for rural residents as regards accessibility and/or affordability, two services, gas and the internet, stand out.

Taking the case of gas first, satisfaction with access is lower in rural areas than in urban areas in all three countries, particularly in the UK and Spain. Additionally, satisfaction with the price of gas in rural areas is lower in the UK and Italy, although not in Spain. Combining this with findings on lower expenditure on gas in rural areas it can be surmised that this reflects: in the UK, significant problems of accessibility and affordability as regards gas in rural areas; in Italy, problems of affordability and, to a lesser extent, accessibility; and, in Spain, considerable problems with accessibility, but not with affordability. Common to rural areas in all three countries are difficulties in accessing gas networks in conditions equal to those in urban areas. Due to service characteristics, gas is not expected to be a universal service in rural areas (see Appendix A in the Supplementary data online). Nevertheless, the evidence found, combined with data on the higher relative expenditure on energy services by rural households noted above in the first section (EUROSTAT, 2005), reflects that rural residents may be paying a higher price for gas, or turning to more expensive energy alternatives. Thus, it is important that affordable energy services which can substitute for gas are available so that rural gas provision does not constitute a disadvantage for residents from the perspective of territorial cohesion.

Turning to the internet, satisfaction with access is lower in rural areas than in urban areas in Italy and Spain. This, combined with lower expenditure on telecommunications, reflects a challenge of accessibility to 
telecommunications services (particularly the internet) in rural areas in both countries. In contrast, this trend is not detected in the UK. This coincides with EUROSTAT data, which show that the digital divide between densely and sparsely populated areas in households' internet access increased to $19 \%$ in Spain and $7 \%$ in Italy in 2006 (12\% and 9\% in 2012, respectively), whilst in the UK this divide did not exist in 2006 or 2012 (EUROSTAT, 2012). Nevertheless, in rural

1220 areas of the UK, satisfaction with the price of fixed telephone and expenditure on telecommunications are lower than in the rest of the country. As use of fixed telephony is often related to use of other telecommunications services, particularly the internet, a problem of affordability for telecommunications may exist in British rural areas.

In contrast, in the cases of electricity and water, problems of accessibility in rural areas are not detected. Similarly, problems around affordability are not ident1230 ified, except for lower satisfaction with the price of water in Italian rural areas. Indeed, in Spain, satisfaction with price of electricity and water is higher in rural than urban areas. The case of water is particularly interesting: in some rural areas in north Spain, where water is abun-

1235 dant due to the combination of low population density and frequent rainfall, autonomous service management by local communities leads to provision at lower prices, or sometimes charge-free provision. This particular approach to water provision is favourable for rural 1240 dwellers, reflected in greater satisfaction with price.

\section{CONCLUSIONS AND POLICY CONSIDERATIONS}

Public infrastructure services are understood as essential for territorial cohesion in the EU (EU, 2007b, 2008, 2011). Acknowledging these services' economic, social and strategic roles, territorial cohesion promotes service provision that does not disadvantage citizens due to their place of residence. Recent evidence shows territorial differences remain as regards the use of public infrastructure services in the EU, but, as noted by BBSR (2013) and RAUHUT and LUDLOW (2013), insufficient research exists on whether these differences amount to disadvantages for residents, thus constituting a concern for territorial cohesion.

To address this question, this paper analysed public infrastructure services provision and regulation in the

1260 EU context from a territorial perspective. To do so, the analyses of RP and SP were combined, a technique that has been scarcely employed in the field of public infrastructure services. This paper is innovative in that it is the first to analyse - to the best of the authors' 1265 knowledge - differences between NUTS-1 and urban and rural areas as regards expenditure on six services and combining these with an analysis of problems of accessibility and affordability in Italy, Spain and the UK.
Results show differences in expenditure on services exist not only between countries, but also between regions. Some regional differences (such as those in energy expenditure, largely explained by different regional climates) reflect the importance of the geographical characteristics of place of residence as affecting consumers' needs and preferences. However, other regional differences are associated with problems of service accessibility, as in cases of the internet in regions with low GDP per capita and for gas in regions with low population density. Moreover, problems of affordability appear more frequently in regions with low GDP per capita. These problems may constitute disadvantages for those living in regions with these characteristics.

Regarding urban-rural differences, results show significant differences in expenditure associated with differences in satisfaction with access and/or price particularly for two services: the internet and gas. This may constitute a disadvantage for rural residents if substitutable affordable services are not available. For the internet, a problem of accessibility is detected in Spanish and Italian rural areas, whilst a problem of affordability affecting telecommunications is detected in British rural areas. In contrast, general problems affecting rural residents are not detected for electricity and water.

From a policy perspective, the results suggest further improvement is necessary to make public infrastructure services more accessible and affordable across all regions, in order to advance territorial cohesion according to the priorities of the Territorial Agenda of the European Union 2020 (EU, 2011) and the new Cohesion Policy 2014-20 (EC, 2011, 2014). Because public infrastructure service provision requires supply networks, accessibility problems may arise in areas where geographical isolation or lower population density makes provision less profitable, such as peripheral regions and rural areas. Even where networks are built and problems of accessibility reduced, affordability issues may occur if market-oriented provision in areas associated with lower profitability means that citizens bear the extra costs. This could be the case, in particular, of the newer technologies, e.g. the internet and mobile telephony, where access may be prioritized first to urban and populated areas, implying an erosion of equality of opportunities (MOLle, 2007).

Furthermore, in a context of socio-economic and technological change, lags in accessing reliable and quality services present a risk for territorial cohesion (ESPON, 2007b; BBSR, 2013). Public infrastructure services are instrumental to develop local externalities, essential for innovation processes and economic development from a territorial dimension (SURIÑACH and Moreno, 2012). Adequate provision of public infrastructure services is important for new regional and rural development policies, that is, investment-oriented approaches to improve endogenous assets and capacities, 
rather than the previous approach of exogenous subsidy and support (WARD and BROWN, 2009). A balanced access to these services is essential for both territorial competitiveness and territorial development, connecting the 'Rebalancing principle', and the 'Growth and development principle' on public infrastructure services regulatory policies (ESPON, 2013).

Public infrastructure services regulation aimed at promoting territorial cohesion should also pay attention to

1330 territorial specificities (ESPON, 2013). Local mechanisms of service regulation, such as self-management of resources and higher levels of network cooperation which characterize rural areas (SøRENSEN, 2012), may work well in these areas. One example is water provision ain, where the traditional organization and management by local communities based on relative water abundance has led to greater price satisfaction in rural areas. This is in stark contrast to one-size-fits-all reforms of water provision which aimed to introduce homogeneous

1340 market solutions independently of the territorial context, critiqued by HALL and LOBINA (2010). Incorporating the territorial perspective into public infrastructure services regulation should promote the consideration of various alternative regimes, which also take into account individual service characteristics.

As argued in the Sixth Cohesion Report (EC, 2014, p. 211), more analysis from a territorial perspective is required on public infrastructure services. According to the third policy ambition described by ESPON

1350 (2013), the 'Territorially oriented principle', this paper also highlights the utility of taking a territorial perspective, not just to regulate these services, but also to evaluate regulation. Hence, the territorial perspective could also be incorporated into new EU regulatory policies oriented to the consumer perspective, as described above in the third section. As recommended by the OECD (2008) and OFGEM (2012), public infrastructure service policies should focus more on potentially vulnerable consumers, a category which should include residents in rural or low populated areas. Renewing information sources that consider the territorial dimension is necessary to overcome methodological nationalism that, as critiqued by JEFFERY and

AQ1 Schakel (2013), neglects the regional dimension 1365 from political analysis. Existing or new sources should incorporate detailed information on region of residence, enabling the extraction of results for a level of regional disaggregation further than NUTS-1, as well as on the characteristics of the place of residence, facilitating analysis of the urban-rural divide.

In the first decade of the 2000s, EU consumer policies and EU cohesion policies advanced, but largely, independently of each other. STRAUSS (2008) argued that insights from consumer behaviour and regional 1375 science need integrating by taking into account the social context inherent to decision-making. Similarly, reinforcing attention to the territorial dimension of public infrastructure services from the perspective of territorial cohesion may decisively contribute to integrating the approaches and development of EU consumer policies and EU cohesion policies. Following FALUDI (2013), this constitutes a major potential contribution of the territorial cohesion approach to EU policies that address territorial development.

Acknowledgements - The authors thank the Office for National Statistics (ONS), the Instituto Nazionale di Statistica (ISTAT) and the Instituto Nacional de Estadística (INE) for microdata listed in the references. Any errors collecting and analysing data are the authors' own.

Disclosure statement - No potential conflict of interest was reported by the authors.

Funding - This research received funding from the European Community's Seventh Framework Programme [Grant Agreement No. 266887 (Project COCOPS)], Socioeconomic Sciences \& Humanities. Judith Clifton acknowledges funding from the Fulbright Schuman Fellowship taken up at Cornell University.

Supplemental data - Supplemental data for this article can be accessed at http://dx.doi.org/10.1080/00343404. 2015.1044958

\section{NOTES}

1. Subsequent surveys omitted the non-users of each service, territorial information, and problems of accessibility and affordability (EC, 2012).

2. To analyse problems of affordability in rural areas, it is important to check whether rural residents have similar economic resources to urban residents. EUROSTAT (2005) data on total consumption expenditure per adult equivalent show this is the case for Italy and the UK. Hence, in these cases, urban-rural differences in satisfaction with service price can be associated with a problem of affordability. However, in Spain, total consumption expenditure is $22.7 \%$ lower in rural than in urban areas. Here, urban-rural differences in price satisfaction are first analysed globally for all services to check if they respond to general differences due to the lower economic resources, or otherwise to a problem of affordability for a particular service (as interpreted in the other countries).

3. These categories correspond, according to the COICOP classification (EUROSTAT, 2005), with the subgroups: Electricity (4.5.1), Gas (4.5.2), Water (4.4.1), and Telephone and telefax services (8.3.1), including internet expenditure.

4. According to the NUTS-1 classification, the UK is divided into 12 regions (Northwest, Northeast, Yorkshire, East Midlands, West Midlands, East England, London, Southeast, Southwest, Wales, Scotland and Northern Ireland), Spain into seven regions (Noroeste, Noreste, Madrid, Centro, Este, Sur and Canarias), and Italy into five regions (Nordovest, Nordest, Centro, Sud and 
Isole). Due to the low number of observations in EC

(2007), both the British regions Northeast and

Yorkshire, and East Midlands and West Midlands, respectively, were aggregated.

\section{REFERENCES}

Bel G., Calzada J. and Fageda X. (2006) Liberalización y competencia en España, Dónde estamos?, Información Comercial Española 829, 123-144.

Bel G., Fageda X. and Mur M. (2010) Por qué se privatizan servicios en los municipios (pequeños)? Evidencia empírica sobre residuos sólidos y agua, Hacienda Pública Española 192, 33-58.

BeL G. and Warner M. (2015) Inter-municipal cooperation and costs: expectations and evidence, Public Administration 93, $52-67$. doi:10.1111/padm.12104

Billón M., Ezcurra R. and Lera-López F. (2008) The spatial distribution of the internet in the European Union: does geographical proximity matter?, European Planning Studies 16, 119-142. doi:10.1080/09654310701748009

Breuer I. M. and Milbert A. (2013) SGI indicators: methodological aspects, in SeGI. Indicators and Perspectives for Services of General Interest in Territorial Cohesion and Development. (Draft) Scientific Report, pp. 146-169. European Observation Network for Territorial Development and Cohesion (ESPON) (available at: http://www.espon.eu).

Bundestinstitut für BAu-, Stadt-, Und Raumforschung (BBSR) (2013) European Atlas of Services of General Interest. BBSR, Bonn.

Clifton J., Comín F. and Díaz-Fuentes D. (2005) Empowering Europe's citizens? On the prospects for the charter of services of general interest, Public Management Review 7, 417-443. doi:10.1080/14719030500181052

Clifton J., Comín, F. and Díaz-Fuentes D. (2006) Privatizing public enterprises in the European Union 1960-2002: ideological, pragmatic, inevitable?, Journal of European Public Policy 13, 736-756. doi:10.1080/13501760600808857

Clifton J. and Díaz-Fuentes D. (2010) Evaluating EU policies on public services: a citizens' perspective, Annals of Public and Cooperative Economics 81, 281-311. doi:10.1111/j.1467-8292.2010.00412.x

Clifton J., Díaz-Fuentes D. and Fernández-Gutiérrez M. (2014) The impact of socio-economic background on satisfaction: evidence for policy-makers, Journal of Regulatory Economics 46, 183-206. doi:10.1007/s11149-014-9251-1

Clifton J., Díaz-Fuentes D. and Revuelta J. (2010) The political economy of telecoms and electricity internationalization in the single market, Journal of European Public Policy 17, 988-1006. doi:10.1080/13501763.2010.499229

Colomb C. and Santinha G. (2014) European Union competition policy and the European territorial cohesion agenda: an impossible reconciliation? State aid rules and public service liberalization through the European spatial planning lens, European Planning Studies 22, 459-480. doi:10.1080/09654313.2012.744384

Conway P. and Nicoletti G. (2006) Product Market Regulation in Non-Manufacturing Sectors in OECD Countries: Measurement and Highlights. OECD Economics Department Working Paper No. 530. Organisation for Economic Co-operation and Development (OECD), Paris.

Corrado G., Corrado L. and Santoro E. (2013) On the individual and social determinants of neighbourhood satisfaction and attachment, Regional Studies 47, 544-562. doi:10.1080/00343404.2011.587797

Costas A. (2007) De consumidor a ciudadano: el papel de la satisfacción del ciudadano en la sostenibilidad de los mercados de servicios públicos, Información Comercial Española 836, 33-50.

Council of European Municipalities and Regions (CEMR) (2009) Response to the Consultation on the 'Green Paper on Territorial Cohesion. Turning Territorial Diversity into Strength'. CEMR, Brussels.

European Centre of Employers and Enterprises Providing Public Services (CEEP) (2010) Mapping of the Public Services. Public Services in the European Union $\mathcal{E}$ in the 27 Member States (available at: http://www.ceep.eu).

European Commission (EC) (2007) Eurobarometer 260: Consumers Opinions on Services of General Interest. EC, Brussels.

European Commission (EC) (2008) Green Paper on Territorial Cohesion. Turning Territorial Diversity into Strength. EC, Brussels.

European Commission (EC) (2010) A Digital Agenda for Europe. EC, Brussels.

European Commission (EC) (2011) Cohesion Policy 2014-2020. Investing in Growth and Jobs. European Union, Luxembourg.

European Commission (EC) (2012) Monitoring Consumer Markets in the European Union (available at: http://ec.europa.eu/ consumers/consumer_research).

European Commission (EC) (2014) Sixth Report on Economic, Social and Territorial Cohesion. Investment for Jobs and Growth: Promoting Development and Good Governance in EU Regions and Cities. EC, Brussels.

European Observation Network for Territorial Development and Cohesion (ESPON) (2007a) ESPON 2013 Programme. European Observation Network on Territorial Development and Cohesion (available at: http://www.espon.eu).

European Observation Network for Territorial Development and Cohesion (ESPON) (2007b) ESPON Project 1.2.3. Identification of Spatially Relevant Aspects of the Information Society. Final Report (available at: http://www.espon.eu).

European Observation Network for Territorial Development and Cohesion (ESPON) (2013) SeGI. Indicators and Perspectives for Services of General Interest in Territorial Cohesion and Development. (Draft) Final Report (available at: http://www.espon.eu).

EUROPEAN UNION (EU) (2007a) Treaty of Lisbon amending the treaty on European Union and the treaty establishing the European Community, Official Journal of the European Union C306/1, 17 December.

EUROPEAN UNION (EU) (2007b) Charter of fundamental rights of the European Union, Official Journal of the European Union C303/ 1, 14 December.

European Union (EU) (2011) Territorial Agenda of the European Union 2020: Towards and Inclusive, Smart and Sustainable Europe of Diverse Regions (available at: http://www.eu2011.hu). 
EUROSTAT (2005) Household Budget Surveys. Statistical Office of the European Communities (EUROSTAT) (available at: http://epp.eurostat.ec.europa.eu), (accessed on 19 July 2014).

EUROSTAT (2006) Regional Statistics. Statistical Office of the European Communities (EUROSTAT) (available at: http://epp. eurostat.ec.europa.eu) (accessed on 23 July 2014).

EUROSTAT (2008) City Statistics. Statistical Office of the European Communities (EUROSTAT) (available at: http://epp. eurostat.ec.europa.eu), (accessed on 23 July 2014).

EUROSTAT (2012) Information Society. Statistical Office of the European Communities (EUROSTAT) (available at: http://epp. eurostat.ec.europa.eu), (accessed on 7 February 2014).

Faludi A. (2013) Territorial cohesion and subsidiarity under the European Union treaties: a critique of the 'territorialism' underlying, Regional Studies 47, 1594-1606. doi:10.1080/00343404.2012.657170

1550 Fiorio C. V. and Florio M. (2011) 'Would you say that the price you pay for electricity is fair?' Consumers' satisfaction and utility reforms in the EU15, Energy Economics 33, 178-187. doi:10.1016/j.eneco.2010.05.006

Fiorio C. V., Florio M., Salini S. and Ferrari P. (2007) European consumers' attitudes on services of general interest: accessibility, price and quality, in Marelli M., Padovano F. and Rizzo I. (Eds) Servici pubblici: nuove tendenze nella regolamentazione, nella produzione e nel finanziamento, pp. 83-110. Franco Angeli, Milan.

Giulietti M., Waddams Price C. and Waterson M. (2005) Consumer choice and competition policy: a study of UK energy markets, Economic Journal 115, 949-968. doi:10.1111/j.1468-0297.2005.01026.x

Hall D. and Lobina E. (2010) Water Companies in Europe 2010. Public Services International Research Unit (PSIRU), University of Greenwich, London.

Instituto Nacional de Estadística (INE) (2006) Encuesta de Presupuestos Familiares. INE, Madrid.

Instituto Nazionale di Statistica (ISTAT) (2006) Indagine sui Consumi delle Famiglie. ISTAT, Rome.

1560 Jefrery C. and Schakel A. H. (2013) Editorial: Towards a regional political science, Regional Studies 47, 299-302. doi:10.1080/ 00343404.2012 .746443

JiLKE S. (2015) Choice and equality: are vulnerable citizens worse off after liberalization reforms?, Public Administration 93, 68-85. doi:10.1111/padm.12102

Keating M. and Stevenson L. (2006) Rural policy in Scotland after devolution, Regional Studies 40, 397-407. doi:10.1080/ 00343400600632820

Mederros E. (2012) Territorial cohesion: a conceptual analysis. Paper presented at the Regional Studies Association European Conference, Delft, the Netherlands, 15 May 2012.

Millward R. (2005) Private and Public Enterprise in Europe: Energy, Telecommunications and Transport, 1830-1990. Cambridge University Press, Cambridge.

Miniaci R., Scarpa C. and Valbonesi P. (2008) Distributional effects of price reforms in the Italian utility markets, Fiscal Studies 29, 135-163. doi:10.1111/j.1475-5890.2008.00071.x

Molle W. (2007) European Cohesion Policy. Routledge, Abingdon.

Northern Ireland Water (2013) Webpage (available at: http://www.niwater.com).

Office of Gas and Electricity Markets (OFGEM) (2012) Proposals for a New Consumer Vulnerability Strategy. OFGEM, London.

Office for National Statistics (ONS) (2006) Expenditure and Food Survey. ONS, London.

Organization for Economic Co-operation and Development (OECD) (2008) Enhancing Competition in Telecommunication: Protecting and Empowering Consumers. OECD, Paris.

Raunut D. and Ludlow D. (2013) Services of general interest and territorial cohesion: what, how and by whom, in SeGI. Indicators and Perspectives for Services of General Interest in Territorial Cohesion and Development. (Draft) Scientific Report, pp. 29-41. European Observation Network for Territorial Development and Cohesion (ESPON) (available at: http://www.espon.eu).

SANTiNHA G. (2014) O principio de coesão territorial enquanto novo paradigma de desenvolvimento na formulação de políticas públicas: (re)construindo ideias dominantes, EURE 40,75-97.

1 SCLAR E. (2015) The political economics of investment utopia: public-private partnerships for urban infrastructure finance, Journal of Economic Policy Reform 18, 1-15. doi:10.1080/17487870.2014.950857

SCOTtish Water (2013) Webpage (available at: http://www.scottishwater.co.uk).

Shucksmith M., Cameron S., Merridew T. and Pichler F. (2009) Urban-rural differences in quality of life across the European Union, Regional Studies 43, 1275-1289. doi:10.1080/00343400802378750

Sørensen J. F. L. (2012) Testing the hypothesis of higher social capital in rural areas: the case of Denmark, Regional Studies 46, 873891. doi:10.1080/00343404.2012.669471

STRAUSS K. (2008) Re-engaging with rationality in economic geography: behavioural approaches and the importance of context in decision making, Journal of Economic Geography 8, 137-156. doi:10.1093/jeg/lbm048

Subacchi P., Pickford S., Tentori D. and Huang H. (2014) Building Growth in Europe: Innovative Financing for Infrastructure. Royal Institute of International Affairs, London.

Suriñach J. and Moreno R. (2012) Introduction: Intangible assets and regional economic growth, Regional Studies 46, 12771281. doi:10.1080/00343404.2012.735087

Suriñach J., Romaní J. and Termes M. (2007) Afecta la banda ancha al crecimiento económico? Evidencia sobre agentes y territorio, Investigaciones Regionales 10, 207-235.

1595 Van De Walle S. (2006) The impact of public service values on service of general interest reform debates, Public Management Review 8, 183-205. doi:10.1080/14719030600587422

Van de Walle S. (2009) When is a service an essential public service?, Annals of Public and Cooperative Economics 80, $521-545$. doi:10.1111/j.1467-8292.2009.00397.x 
Van Dooren W. and Van de Walle S. (2008) Reality is merely an illusion, albeit a persistent one: introduction to the performance measurement symposium, International Review of Administrative Sciences 74, 531-534. doi:10.1177/0020852308098466

Ward N. and Brown D. L. (2009) Placing the rural in regional development, Regional Studies 43, 1237-1244. doi:10.1080/ 00343400903234696

1655

Warner M. and Clifton J. (2014) Marketization, public services and the city: the potential for Polanyian counter movements, Cambridge Journal of Regions, Economy and Society 7, 45-61. doi:10.1093/cjres/rst028

Whitehead J. C., Pattanayak S. K., Van Houvten G. L. and Gelso B. R. (2008) Combining revealed and stated preference data to estimate the nonmarket value of ecological services: an assessment of the state of the service, Journal of Economic Surveys 22, 872-908. doi:10.1111/j.1467-6419.2008.00552.x

Wishlade F. G. (2008) Competition and cohesion - coherence or conflict? European Union regional state aid reform post-2006, Regional Studies 42, 753-765. doi:10.1080/00343400701291575 